\title{
The Effectiveness of Two Soil Amendments: Gypsum and Polyacrylamide on Soil Erosion under Saline Conditions in Australia
}

\author{
Bahar Nader Al-Uzairy
}

\begin{abstract}
This study investigates the interaction and the effectiveness of two soil amendments: Gypsum and Polyacrylamide (PAM) in minimizing soil erosion under saline condition. Erosion measurements were carried out on a sandy loam soil in the $1 \mathrm{~m} \times 6 \mathrm{~m}$ Flume of Griffith University's rainfall simulation facility (GUTSR). The results presented in this study suggest that by moderately increasing soil salinity (increasing EC from 0.5 to $4 \mathrm{dS} / \mathrm{m}$ ). Soil erosion, as expressed in terms of sediment concentration and soil loss increased substantially. Sediment concentration increased 3.6 times and soil loss 4.6 times when compared with non-saline (control) soil. These findings have some important practical implications for agriculture on saline land. PAM can be successfully used for controlling or minimizing the adverse impacts of salinity such as increased erosion, surface sealing, and poor runoff water quality.
\end{abstract}

Index Terms-Climate change, soil salinity, soil erosion, gypsum and polyacrylamide.

\section{INTRODUCTION}

Population growth is putting increasing demand for food and fiber worldwide, while land and water resources are becoming scarce [1]. Increasing food and fiber production requires water to be used more efficiently in irrigated crop growing, as well as forcing farmers to use marginal or moderately saline lands and water resources. Saline water was found to be one of the reasons for the increased soil salinity problem around the world [2].

Soil salinity and soil erosion of agricultural land are major concerns across worldwide. For example, statistics showed that around $\$ 130$ million worth of agricultural production is lost every year in Australia due to salinity and related effects [3], [4].

Salinization of land and water resources is the major land degradation challenge facing most countries, which leads to decline in agricultural productivity [3], [5], [6] For instance, in Queensland about 15,000 hectares of land are under the threat of induced salinity. Forecasts for 2050 are more worrying, which suggest close to a million hectares of land being under threat of salinity [7], leading to major government expenditures on amendments efforts [3], [8]. A growing land degradation problem in many parts of the world is the interaction between soil salinity and erosion. The soil loss cause by this interaction is highly significant, implying a loss to the agricultural potential of the affected

Manuscript received June 15, 2014; revised August 11, 2014.

Bahar Nader Al-Uzairy is with College of Agriculture Baghdad University, Baghdad (e-mail: baharmns@yahoo.com). lands [9]. However, the adversity of the effects of soil salinity and soil erosion not only affects humans, but also severely affects water bodies and marine life, as well as causing loss of biodiversity.

The main types of salinity: dryland and irrigated land salinity have a higher impact on human activities and vegetation cover across Australia [10], [11]. "Reference [7] for instance, indicates that close to 5.7 million hectares of land are currently at risk or are affected by dryland salinity" and that this could triple within 50 years [5], [6]. Unfortunately, research on such problems is limited and very little information in Australia and worldwide available so far, about the interaction between salinity and erosion, and the subsequent implications for sediment loss through runoff [6]. There has been little emphasis on the interaction between soil erosion and salinity, because salinity, which is associated with flat lands, has not been linked to soil erosion in the past, which is normally associated with sloping lands. As more and more marginal lands and water are being used for agriculture, however, the overlaps between the two are increasing. Erosion can lead to break down of soil aggregate, which ultimately leads to soil salinity [12], while soil salinity affects vegetation cover leaving the land bare and prone to erosion. Soil structure therefore, is an important factor for land degradation processes and a useful factor in explaining the reason beyond researchers' emphases of the use of amendments to control both problems and their interaction. Natural factors may cause these processes but, as [11], pointed out; it is the human action that magnifies these problems. Specifically, the study examined the interaction between the two degradation processes of salinity and erosion, and attempts to find out whether or not adding the two amendments of Polyacrylamide (PAM) and gypsum to soils has lasting effect on reducing soil erosion under saline condition. The impact of these amendments on soil erosion, water quality, infiltration, and runoff rate was studied under GUTSR (Griffith University Tilting-flume Simulation Rainfall) facilities. In other words, the current study seeks to answer the following research questions:

- What is the impact of moderately increased soil salinity on soil erosion?

- What are the impacts of soil amendments on soil salinity, soil erosion and their interactions?

\section{LITERATURE REVIEW}

The global population is increasing day by day and has been estimated to reach 9.0 billion by 2050 [13], [14], Most of this population growth is happening in the developing 
countries and it is not easy for many of these countries to meet the needs of their growing population for food and fibre. To overcome this predicament, there is a dire need to increase crop productivity either by increasing area under cultivation or through increase in yield per unit area [15], [16]. Most problem due to free good soils of the world have already been used and any expansion of agriculture land has to happen on land with limitations of one sort or the other, including salinity. More important than expanding agricultures into problem lands is to prevent good agricultural lands becoming degraded or salinized, which is happening at a rapid rate all over the world.

In Australia, salinity causes major land and water degradation [6], [17] and [18]. Approximately 5.7 Mha of land is presently at threat or affected by dryland salinity [5], [12]. In addition to this, by 2050 up to $20,000 \mathrm{~km}$ of streams could be significantly affected by salt [6], [18]. It is believed that over 50,000 hectares of land in Queensland have been adversely affected by salinity [17], [19].

In addition, Queensland's agricultural landscape features varied types of soils, where in some are ancient, heavily weathered and infertile, and are normally deficient in nitrogen and phosphorus. Such soils are of good quality for agricultural use and as such, nitrogenous and superphosphate fertilizers are widely applied to alleviate the nutrient deficiencies especially in cereal and pastures lands [20]. Such heavy fertilization can contribute to soluble salt accumulation and eventual salinity. Most Queensland soils are characterized by a high susceptibility to water logging and a fragile soil structure due to simultaneous activities of salinization and erosion [21], [22].

In relation to salinity and erosion, although much has been documented about the issues related to salinity and erosion individually, little research has been done in regards to how increased salinity is associated with higher rates of run-off induced erosion [7]. This linkage is based on the fact that salinization has adverse effects on the growth of cultivated plants, while soil erosion destroys the farmland. In Australia, salinity is a widespread problem cases, which the dying off of shrubs and trees [23]. Studies have shown that as plants die and land becomes exposed to rain and runoff, erosion rate will increase.

Salinity can degrade the soil by adversely affecting its physical and chemical properties of the soil [12]. Research has shown that the type of soil has a big influence on the rate of sediment loss by erosion, with or without the presence of salinity. However, sediment load of various soil types increases with an increased level of salinity. Salinity lowers the aggregate stability of soil; hence increases the rate of sediment loss. "Reference [24] observed increased soil losses following increased soil ESP in a study on two loamy and one clay soil using a rainfall simulator and employing a similar experimental set up as used by Ghadiri and his co-workers [25]. Other studies have also shown that soil loss increases with increasing salinity and sodicity associated with the use of effluent water [26]-[28].

\section{METHODS}

The methods and the experiments used in this study are explained below.

\section{A. Soil Erosion Experiments in GUTSR Facility}

In this study a sandy loam soil from Toohey Forest area, whose properties are given in Table I, was used for all the experiments. The soil was transported to the GUTSR site and stored in the soil bay near the flume of the GUTSR When everything was ready for the start of the experiments the soil was lifted into the flume of the GUTSR, spread uniformly and levelled along the length and the width of the flume to prevent preferential flow taking place during the experiments. The soil bed in all experiments in this study is 6 metres long, 1 metre in width and $0.1 \mathrm{~m}$ deep. Rainfall was set at $100 \mathrm{~mm} /$ hour and the simulation was carried out for 20 minutes periods, as shown in Table I.

TABLE I: PHYSICAL AND CHEMICAL CHARACTERISTICS OF THE SOIL BEFORE AND AFTER INCREASING THE SALINITY

\begin{tabular}{|c|c|c|c|}
\hline \multirow{2}{*}{\multicolumn{2}{|c|}{ Properties }} & \multicolumn{2}{|l|}{ Value } \\
\hline & & Before & After \\
\hline & Sand $(\%)$ & 79 & 79 \\
\hline & Silt $(\%)$ & 6 & 6 \\
\hline & Clay $(\%)$ & 15 & 15 \\
\hline \multicolumn{2}{|c|}{ Soil textural class } & $\begin{array}{l}\text { Sandy } \\
\text { Loam }\end{array}$ & $\begin{array}{l}\text { Sandy } \\
\text { Loam }\end{array}$ \\
\hline \multirow{2}{*}{\multicolumn{2}{|c|}{$\begin{array}{c}\text { PH } \\
\begin{array}{c}\text { Electrical Conductivity of } 1: 5 \text { suspension } \\
(\mathrm{dS} / \mathrm{m})\end{array}\end{array}$}} & 5.19 & 8.6 \\
\hline & & 0.1 & 0.81 \\
\hline \multicolumn{2}{|c|}{ Exchangeable $\mathrm{Ca}(\mathrm{mmoles}+/ \mathrm{kg})$} & 1.5 & 0.99 \\
\hline \multicolumn{2}{|c|}{ Exchangeable $\mathrm{Mg}$ (cmoles $+/ \mathrm{kg}$ ) } & 0.5 & 0.4 \\
\hline \multicolumn{2}{|c|}{ Exchangeable $\mathrm{Na}(\mathrm{cmoles}+/ \mathrm{kg})$} & 0.2 & 0.6 \\
\hline \multicolumn{2}{|c|}{ Exchangeable K (cmoles $+/ \mathrm{kg}$ ) } & 1.2 & 0.001 \\
\hline \multicolumn{2}{|c|}{ Cation Exchange Capacity (cmoles+/kg) } & 3.4 & 2 \\
\hline \multicolumn{2}{|c|}{ Exchangeable Sodium Percentage (ESP)\% } & 5.9 & 30 \\
\hline \multicolumn{2}{|c|}{ Sodium Adsorption Ratio (SAR) } & 0.2 & 0.72 \\
\hline \multicolumn{2}{|c|}{ Exchangeable Sodium Ratio (ESR) } & 6.3 & 42 \\
\hline \multirow{3}{*}{ Soil Type } & \multirow{2}{*}{ Australian system } & Category & Category \\
\hline & & 0 & $1 \& 2$ \\
\hline & USDA system & $\begin{array}{c}\text { Non } \\
\text { saline }\end{array}$ & $\begin{array}{c}\text { Saline- } \\
\text { sodic }\end{array}$ \\
\hline
\end{tabular}

\section{B. Control Experiment (Untreated and Non-Saline Soil)}

The soil bed for this experiment was saturated overnight with tap water at zero precent flume slop. The prepared saturated soil bed in the flume was put on $1 \%$ slope and rainfall experimentt commenced and continued for 20 minutes. Sediment plus runoff was collected every 2 minutes during the simulation process in $500 \mathrm{ml}$ preweighed beakers. The time taken to fill up each beaker was recorded and the volume of collected solution was accurately measured for the determination of runoff rate and its possible variation with time during the 20 minutes simulation run. This experiment aimed at explaining the base line condition and how the rainfall affects erosion of untreated soil. Replication, though time consuming and expensive, was carried out for some flume runs if inconsistency was observed.

\section{Experiment with Saline Soil}

After the completion of control experiment, the soil was removed from the flume and replaced with a fresh load of the same soil. Soil bed preparation was the same as for experiment 1 but the soil was saturated with a saline 
solution of EC $=4 \mathrm{dS} / \mathrm{m}$, as illustrated below in Fig. 1. This level of salinity was chosen as lands and water with this level of salinity are considered marginal for agriculture. The flume was then put on $1 \%$ slope and the rainfall experiment commenced and continued for 20 minutes, in the same way as for experiment 1. Sediment plus runoff was collected every 2 minutes during the simulation process in $500 \mathrm{ml}$ pre-weighed beakers. The aim of these experiments was to determine whether the increased salinity had affected soil erosion and runoff rate when compared to the control experiment.

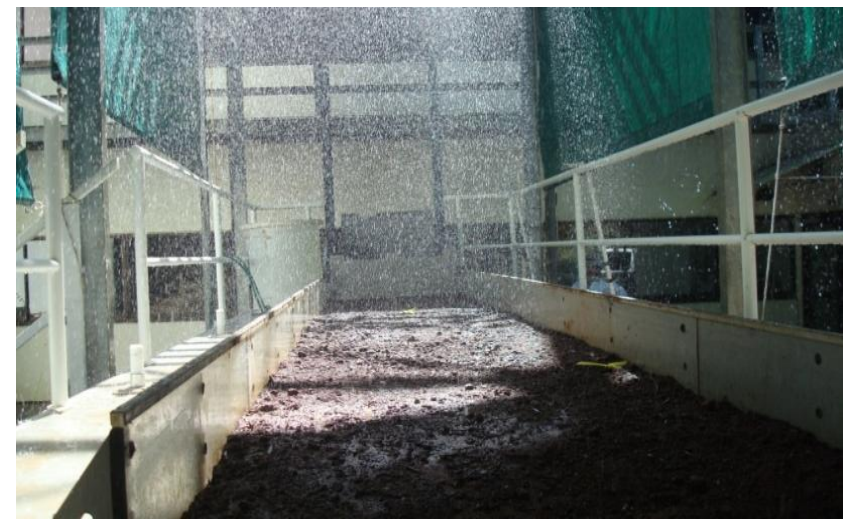

Fig. 1. Flume during the rainfall simulation.

\section{Experiment with Gypsum Treated Soil (Saline + Gypsum)}

Once again the soil was replaced in the flume in preparation for this experiment. The soil for this experiment was pre-mixed with commercial gypsum (Chicago, Ill.). The manufacturer's assay indicated $83 \%$ minimum calcium sulphate as $\mathrm{CaSO}_{4} \cdot 2 \mathrm{H}_{2} \mathrm{O}$, minimum $19.3 \% \mathrm{Ca}$ equivalent, and minimum $15.4 \% \mathrm{~S}$ equivalent. Gypsum pre-mixed at the rates recommended in the literature as being the most effective in reducing erosion under non-saline condition; i.e. 10 tons/ha $\left(1000 \mathrm{~g} / \mathrm{m}^{2}\right)$. The gypsum was mixed with the soil surface by hand and then the soil surface levelled [29], [30]. This soil was then put in the flume and saturated with saline solution overnight in the same way as for Experiment 2 above. The saturated soil bed was put on $1 \%$ slope and rainfall experiment was commenced and continued for 20 minutes the same way as the previous two experiments. Sediment plus runoff was once again collected every 2 minutes during the simulation process in $500 \mathrm{ml}$ preweighed beakers. All other sample handling and measurement procedures were the same as experiments one and two.

\section{E. Experiment on PAM Treated Soil (Saline + PAM)}

The soil for this experiment was first air-dried then mixed with a dry PAM (923SH); (see Fig. 2 sample from SNF Australia) for the molecular weight of different PAM products. Dry PAM mixed at the rate recommended in the literature as being the most effective in reducing erosion under non-saline condition; is $40 \mathrm{~kg} / \mathrm{ha}\left(4 \mathrm{~g} / \mathrm{m}^{2}\right)$ [30], [31]. This soil was then put in the flume and saturated with saline solution overnight in the same way as for Experiment 2 and 3 above.

The flume then was put on $1 \%$ slope and rainfall experiment commenced and continued for 20 minutes (Fig.
3). Sample collection, handling and analysis were the same as previous experiments.

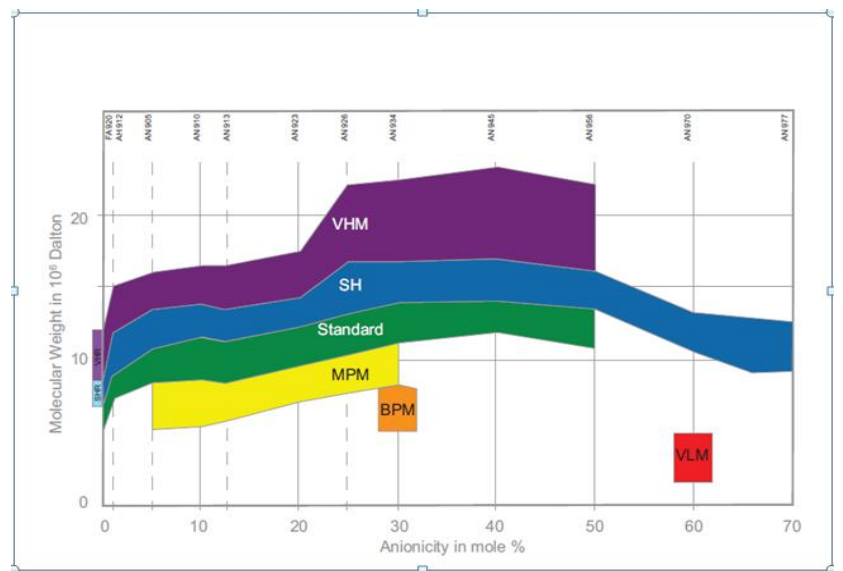

Fig. 2. PAM types and their molecular weight (curtsey of SNF Australia).

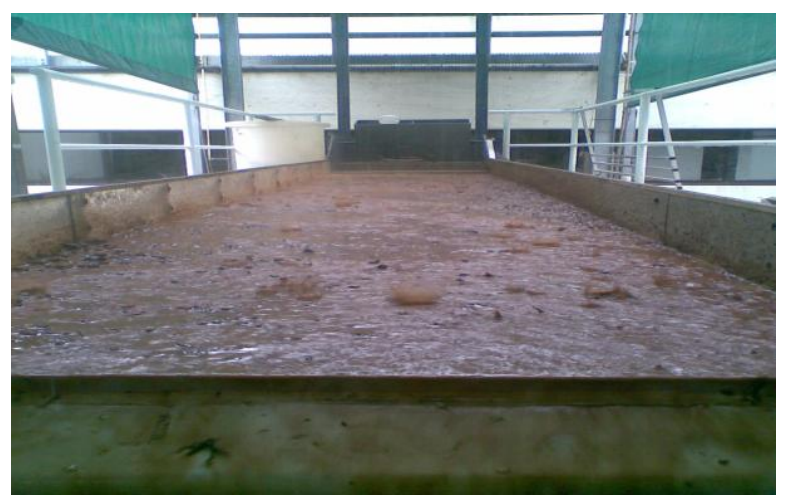

Fig. 3. Flume during the experiment.

\section{Discussion AND ANALYSIS}

Results from these set out experiments indicated that there were changes in sediment concentration with runoff duration for all treatments (control, saline, saline+ gypsum and saline+ PAM), as shown in Fig. 4. The results indicate that sediment concentrations was highest in the early stage of the experiment for all four treatments, with maximum values of $7.06 \mathrm{~g} / \mathrm{L}, 21.60 \mathrm{~g} / \mathrm{L}, 28.547 \mathrm{~g} / \mathrm{L}$ and $8.73 \mathrm{~g} / \mathrm{L}$ for control, saline, saline +gypsum and saline +PAM respectively. Sediment concentration decreased with time from its highest level for all treatments until it reached a steady state at around 10 to 12 minutes into the rainfallrunoff events. The level of sediment concentration measured during the experiments could be related to the detachment and transport of the finer particles which were more abundant in the original soil at the early stages of the experiments. The sharp decline in sediment concentration with time, shown in Fig 4 has been reported by many researchers and for all kinds of soils [12], [32]-[36], while the patterns of change with time in sediment concentration were the same for all four treatments, the results of statistical analysis showed that there were significant differences among treatments at $p<0.05$ level of significance. In Fig. 4 curves of the form of power lines provide good fit to each data set with very high $R^{2}$. Around 10 to 12 minutes after the start of experiments the change in sediment concentration with time became negligible and the system approached steady state. 


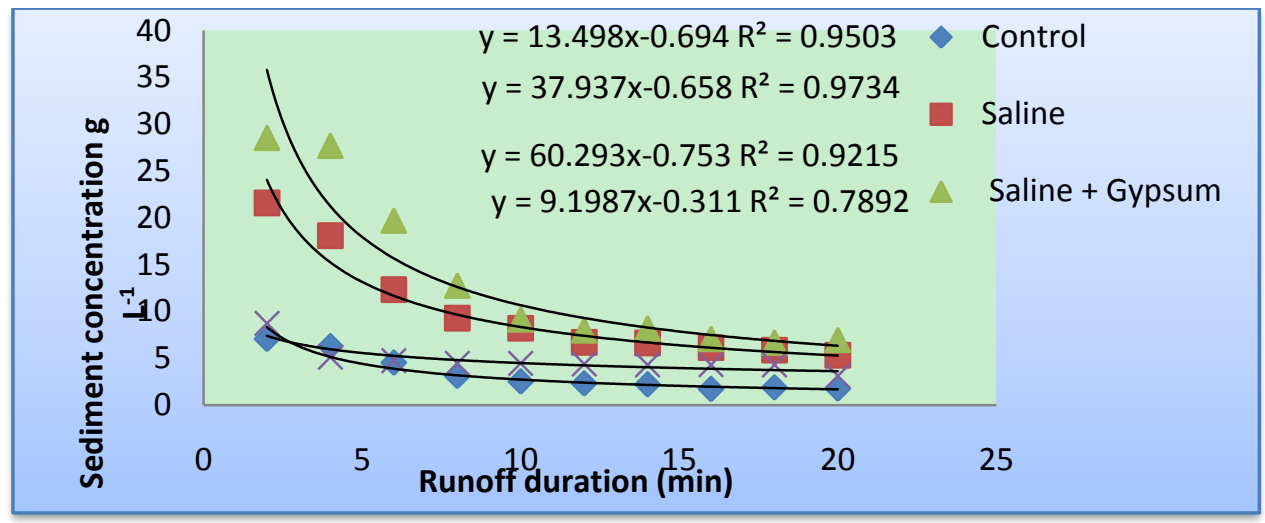

Fig. 4. Sediment concentration change with time for the all four treatments.

After reaching the steady state condition, a test of significance was carried out to see whether the differences among treatments were still statistically significant. The results showed that sediment concentration increased significantly $(P<0.05)$ when soil salinity was increased. The mean value for saline treatment was $(6.1 \mathrm{~g} / \mathrm{L}$, while it was $1.7 \mathrm{~g} / \mathrm{L}$ ) for control treatment. These results confirmed that a moderate increase in soil salinity (raising the EC to 4 $\mathrm{dS} / \mathrm{m}$ ) significantly increased soil erosion, through reducing aggregate stability and increasing soil desperation, as shown in Fig. 4 and Fig. 5, significantly reduced sediment concentration when compared with the salinity treatment without PAM.

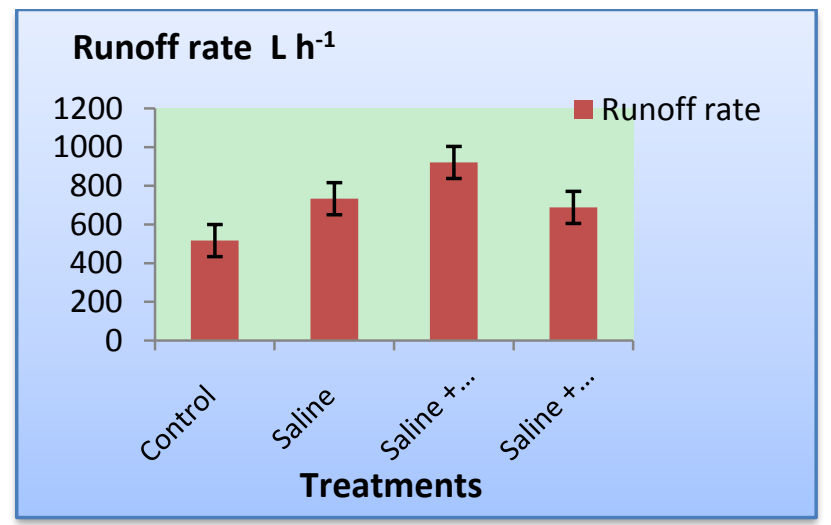

Fig. 5. Means runoff rates for treatments at steady state.

The findings suggest that PAM is an effective soil amendment not only in non-saline soils but also under saline soil. Soil amendment "gypsum" behaves differently from PAM. The results indicate that there is a significant difference at $P<0.05$ between gypsum + salinity and salinity with no gypsum treatments. Gypsum application to saline soil significantly increased sediment concentration, when compared with the saline treatment without gypsum. The mean value for saline treatment was $6.1 \mathrm{~g} / \mathrm{L}$, while it was $4.2 \mathrm{~g} / \mathrm{L}$ and $7.4 \mathrm{~g} / \mathrm{L}$ for saline $+\mathrm{PAM}$ and saline + gypsum treatments respectively.

Importantly, soil loss for control, saline, saline +gypsum and saline + PAM as presented in Table II show that soil loss from saline treatments is higher than the non-saline control treatment. Soil loss increased 360\% from saline soil compared with non-saline (control) treatment. For a region with a $1000 \mathrm{~mm}$ of rain per year, the loss from saline land in equivalent to $13.8 \mathrm{Tons} / \mathrm{ha} / \mathrm{yr}$, which is very large and damaging to Australian land. Adding gypsum to this soil resulted in further increases in soil loss up to $21 \mathrm{Tons} / \mathrm{ha} / \mathrm{yr}$.

TABLE II: MEAN SOIL LOSS FOR ALL TREATMENTS

\begin{tabular}{|c|c|c|c|}
\hline \multicolumn{4}{|c|}{ Mean soil loss after reaching steady state } \\
\hline Treatments & $\left(\mathbf{g m} / \mathbf{m}^{\mathbf{2}} / \mathbf{m i n}\right)$ & $\left(\mathbf{g m} / \mathbf{~ m}^{\mathbf{2}} / \mathbf{h}\right)$ & $(\mathbf{T o n} / \mathbf{h a} / \mathbf{y r})$ \\
\hline Control & 0.5 & 30 & 3.0 \\
\hline Saline & 2.3 & 138 & 13.8 \\
\hline Saline + Gypsum & 3.5 & 210 & 21 \\
\hline Saline + PAM & 1.2 & 73.8 & 7.4 \\
\hline
\end{tabular}

Fig. 4 and Fig. 5 clearly show that the application of soil amendment PAM to a saline soil is beneficial in minimizing soil erosion. PAM plays an important role in improving saline soils by keeping them well-aggregated and strengthening soil surface during rainfall events thus reducing soil erodibility and total soil loss. Also, PAM increases soil infiltration rate leading to reduction in surface runoff and soil loss. Our findings are in line with those of the other researchers working on non-saline or saline soils such [37], while others also reported that PAM is more effective in reducing erosion when applied to soil saturated with high EC water [38].

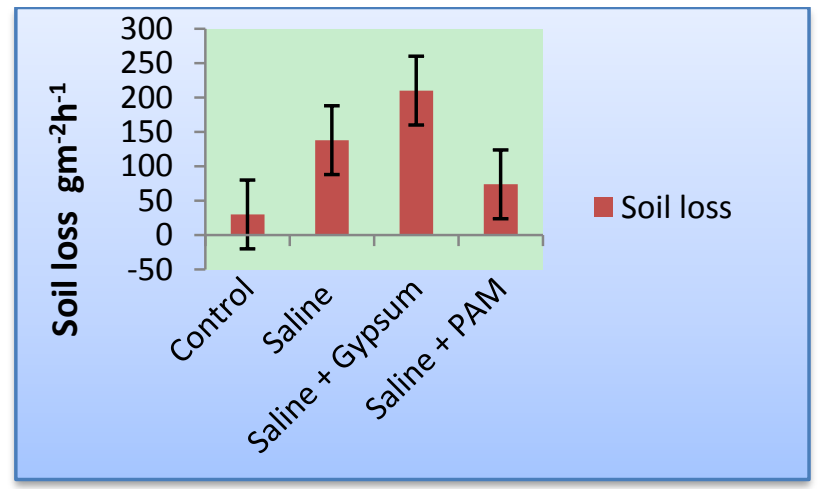

Fig. 6. Means of soil loss for all treatments after reaching steady state.

The results of the current study suggest that gypsum application to saline soil increase the rate of erosion. Gypsum has been one of the important soil amendments used to reduce soil erosion in many different kinds of nonsaline soils but it is totally ineffective under saline condition.

\section{CONCLUSIONS AND IMPLICATIONS}

Many Australian soils have salinity and erosion problems that limit crop production and increase land degradation. 
Salinization increases the dispersion rate of soil and increases the ratio of small aggregates over larger ones. A decrease in mean aggregate size is an indication of breakdown of large aggregates into small ones following the impact of raindrop, which is aggravated by increases in soil salinity [9]. Soils with high sand fraction, similar to the one used in this study, are particularly susceptible to erosion and salinity and are in need of the addition of soil amendments for sustained production. The results of this study, carried out using the GUTSR facility, demonstrated that soil erosion and sediment transport from saline soils could be minimized by treating the soil with small amount of high molecular weight of PAM. The addition of PAM to sandy loam soil in this study under saline condition appears to have reduced its degradation by minimising runoff, and reducing sediment concentration and total soil loss. PAM polymer improves surface soil by, increasing aggregate stability, enhancing soil structure, increasing infiltration thus reducing the erodibility of saline soil.

These findings have some important practical implications for agriculture on saline land. PAM can be successfully used for controlling or minimizing the adverse impacts of salinity such as increased erosion, surface sealing, and poor runoff water quality. A moderate rate of PAM application $(40 \mathrm{Kg} / \mathrm{ha})$ is therefore recommended for soils with border line salinity such as the one used in this research. The potential for PAM application for erosion control under saline condition can increase if we learn more about PAM and its properties, and so there is a need for more research on PAM under different types of soil and with different levels of salinity. PAM application can also bring other environmental and economical benefits by reducing damages caused to environment by transported sediment and pollutants.

\section{REFERENCES}

[1] G. J. Hoffman and R. E. Evans, Design and Operation of Farm Irrigation, $2^{\text {nd }}$ ed. USA: St. Joseph, Michigan, 2007, pp. 1-32.

[2] F. Ghassemi, A. J. Jakeman, and H. A. Nix, Stalinization of Land and Water Resources: Human Causes, Extent, Management and Case Studies, The Australia National University, Canberra, Australia, and CAB International, Wallingford Oxon, UK, 1995.

[3] Australian Government. (2009a). Salinity-Impacts. [Online]. Available: http://www.anra.gov.au/topics/salinity/impacts/index.html

[4] Australian Government. (2009b). Salinity-Impacts and CostsQueensland. [Online]. Available: http://www.anra.gov.au/topics/salinity/impacts/qld.html

[5] Australian State of the Environment Committee, Australia: State of the Environment, Melbourne, Victoria: CSIRO Publishing, 2001.

[6] Webb. Dryland Salinity Risk Assessment in Queensland. (2002) Report prepared for the Consortium for Integrated Resource Management. [Online]. http://www.cirm.org.au/pdf/salinity.pdf

[7] National Land and Resources Audit, Australian agriculture assessment. (2001). National Land and Water Australia. [Online]. p. 129.

Available: http://www.anra.gov.au/topics/agriculture/pubs/national/agriculture_c ontents.html.

[8] K. Edwards, "Soil erosion and conservation in Australia," in World Soil Erosion and Conservation, D. Pimentel, Ed. 2010, pp. 147-170.

[9] T. B. Ribolzi, A. Casenave, J. P. Delhoume, J. Ducloux, and V. Valles, "Hydrochemistry of runoff and subsurface flow within Sahelianmicrodunes," European Journal of Soil Science, vol. 54, pp. 531-542, 2003.

[10] M. Neave and S. Rayburg. "Salinity and erosion: A preliminary investigation of soil erosion on a salinized hillslope" in Sediment Dynamics and the Hydromorphology of Fluvial Systems, J. S. Rowan, R. W. Duck, and A. Werritty, Eds. IAHS Publication, 2006.
[11] Commonwealth of Australia, A National Action Plan for Salinity and Water Quality in Australia: Canberra, 2000.

[12] H. Ghadiri, J. Hussein, and W. Rose, "A Study of the Interactions between salinity, soil erosion, and pollutant transport on three Queensland soils," Australian Journal of Soil Research, vol. 45, pp. 404-413, 2007.

[13] World Population Policies, 2005, United Nations, Department of Economic and Social Affairs, March 2006.

[14] R. Lal, "Soils and sustainable agriculture," Agron. Sust. Dev., p. 8, 2007.

[15] S. M. Wilson, "Dryland and urban salinity costs across the MurrayDarling Basin," An Overview and Guidelines for Identifying and Valuing the Impacts, Murray-Darling Basin Commission, Canberra, 2004.

[16] R. Lal, "Soil degradation by erosion," Land degradation and Development, vol. 12, pp. 519-539, 2001.

[17] C. Trevor and K. Kenyon. (2004). What is salinity? Queensland government. [Online] Available: http://www.qld.waterwatch.org.au/schools/pdf/resource_book_a.pdf

[18] H. Ghadiri, I. Dordipour, M. Bybordi and M. J. Malakourti, "Potential use of Caspian Sea for supplementary irrigation in North Iran," Agriculture of Water Management., vol. 79, pp. 209-22, 2004.

[19] K. Nossal and P. Gooday, "Raising Productivity Growth in Australian Agriculture," Issues Insights, Australian Bureau of Agricultural and Resource Economics, vol. 9, p. 7, 2009.

[20] A. T. P. Ivey, "The current cost of dryland salinity to agricultural landholders in selected Victorian and New South Wales catchments," Ivey ATP Report, Murray-Darling Basin Commission and the National Dryland Salinity Program, Canberra, 2000.

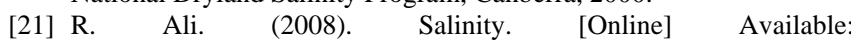
http://www.clw.csiro.au/publications/factsheets/SalinityFactSheet.pdf

[22] R. Yeo, S. A. Flowers, G. Rao, K. Welfare, N. Senanayake, and T. J. Flowers, "Silicon reduces sodium uptake in rice (Oryzasativa L.) in saline" The Global Problems of Salt Affected Soil, Acta. Agronomica Hungarica, vol. 36, pp. 159-172.

[23] I. Mamedov, I. Shainberg, and G. J. Levy, "Rainfall energy effects on runoff and interrill erosion in effluent irrigated soils," Soil Science, vol. 165 , pp. 535-544, 2000.

[24] Commonwealth of Australia, Developing and Using Program Logic In Natural Resource Management, 2009.

[25] H. Ghadiri, C. W. Rose, and W. L. Hogarth. "The Influence of grass and porous barrier strips on runoff hydrology and sediment transport," Transactions American Society of Agricultural Engineers, vol. 44, pp. 259-268, 2001.

[26] I. Mamedov, G. J. Levy, I. Shainberg, and J. Letey. "Wetting rate, sodicity and texture effects on infiltration rate and runoff," Australian Journal of Soil Research. vol. 39, pp. 1293-1303, 2001.

[27] G. J. Levy, D. Goldstein, A. I. Mamedov et al., "Prewetting rate and sodicity effect on the hydraulic conductivity of soils," Australian Journal of Soil Research, vol. 36, pp. 1279-1291, 2001.

[28] G. J. Levy, A. I. Mamedov et al., "Prewetting rate and sodicity effects on soil permeability and surface sealing," Acta. Horticulture, vol. 573, pp. 21-28, 2002.

[29] A. Rose and H. Ghadiri, "Transport and enrichment of soil-sorbed chemicals," in Modelling the Fate of Chemicals in the Environment Centre for Resource and Environmental Studies, I. Moore, Ed. Australian National University, Canberra, pp. 90-101, 1991.

[30] Shainberg, M. E. Summer, W. P. Miller, M. P. Farina, M. A. Pavan, and M. V. Fey, "Use of gypsum on soil: a Review," in Advances in Soil Science, B. A. Stewart, Ed. pp. 91-101, 1989.

[31] T. Bariac, A. Casenave, J. P. Delhoume et al., "Hydrochemistry of runoff and subsurface flow within Sahelianmicrodunes," European Journal of Soil Science, vol. 54, pp. 531-542, 2003.

[32] P. B. Hairsine and C. W. Rose, "Rainfall detachment and deposition: Sediment transport in the absence of flow-driven processes," Soil Science Society of America Journal, vol. 55, pp. 321-324, 1991.

[33] R. P. C. Morgan, D. D. V. Morgan, and H. J Finney. "A predictive model for the assessment of erosion risk," Journal of Agricultural Engineering Research., vol. 30, pp. 245-253, 1984.

[34] W. Rose, J. R. Williams, G. C. Sander, and D. A Barry, "A mathematical model of soil erosion and deposition processes. I. Theory for a plane land element," Soil Science society of America Journal, vol. 47, pp. 991-995, 1983.

[35] H. Ghadiri and D. Payne, "Raindrop impact stress and the breakdown of soil crumbs," Journal of soil Sciences, vol. 28, pp. 247-258, 1977.

[36] H. Ghadiri and D. Payne, "Raindrop impact and soil splash," in Soil Physical properties and Crop production in the Tropics, D. G. Greenland and R. Lal, Eds. John Wiley and Sons: London, 1979, pp. 95-105. 
[37] R. Peterson, D. C. Flanagan, and J. K. Tishmack, 2002a, "Polyacrylamide and gypsiferous material effects on runoff and erosion under simulated rainfall," Transactions of the American Society of Agricultural Engineers, vol. 45, pp. 1011-1019.

[38] A. Roa-Espinosa, G. D. Bubenzer, and E. S. Miyashita, "Sediment and runoff control on construction sites using four application methods of polyacrylamide mix," American Society of Agricultural Engineers, 1999.

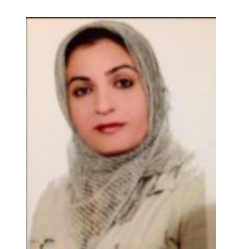

Bahar Nader is a lecturer in the College of Agriculture, Department of Soil and Water Sciences at Bagdad University. Bahar has a master degree in environment science from Griffith University in Australia. She has over 10 years teaching and research experience in the field of environment sciences. Her research interests include soil science, soil salinity and climate change. 